\title{
Debating Identity: Reflections on Coverage of Dharahara and Käṣ̣thmaṇdap Post Gorkha-Earthquake 2015
}

\author{
Abhas Dharananda Rajopadhyaya
}

\begin{abstract}
The 7.8 $\mathrm{M}_{\mathrm{w}}$ Gorkhāa-earthquake in April 2015, took 8,857 lives, injured 21,952, destroyed 755,549 buildings, 581 heritages and cost an estimated approximate $\$ 513.38$ billion. Many heritage sites, including those enlisted in the World Heritage Site, were damaged due to this disaster. The fall of Dharahara , among all cultural-historical sites, was given (un) due attention by many national media, owing to high number of deaths and as a popular landmark of the city. This modern elite tower structure was presented as symbol of national unity and of 'rising back'. But there are other important public heritages too - many centuries older than Dharahara and they too had stories of deaths, of injuries and of survivals, but received a very small space or almost none in the national media. I take an example of Käșthamandap that hosted over 54 people during the earthquake. I have used the method of qualitative content analysis to discuss the construction of identity by national media.
\end{abstract}

Keywords: Gorkha earthquake, heritage, Kasthamandap, Dharahara, media coverage, qualitative analysis, reconstruction, identity 


\section{Background}

Nepal has, for centuries, been prone to disasters, including earthquakes with major ones hitting almost once every century. Earthquakes, from the historically recorded $1223 \mathrm{AD}$ (1280 BS) earthquake ${ }^{1}$ or that of 1255 AD (NS 375 or 1312 BS) claiming life of reigning King Abhaya Malla (reign: 1216 - $1255 \mathrm{AD}$ ) and one-third of the city population to as recent as those in $1834 \mathrm{AD}, 1934 \mathrm{AD}$ and now $2015 \mathrm{AD}$ are major ones of the respective centuries that proved disastrous for the nation.

The recent $7.8 \mathrm{M}_{\mathrm{w}}$ Gorkha $\bar{a}$-earthquake is the biggest of the century, claiming 8,857 lives and injuring $21,952^{2}$, destroying 755,549 buildings, 581 heritages and costing a damage and loss worth $\$ 513.38$ billion. It has been followed by 418 number of aftershocks with local magnitude of greater than or equal to $4.0 \mathrm{M}_{\mathrm{w}}{ }^{3}$, including major ones of 26 April (at 12:54:08 measuring 6.7 $\mathrm{M}_{\mathrm{w}}$ ) and that of 12 May (at 12:50 measuring $7.3 \mathrm{M}_{\mathrm{w}}$, followed by another $6.3 \mathrm{M}_{\mathrm{w}}$ shock only

\footnotetext{
${ }^{1}$ Pant (2013) enlists a total of 22 recorded earthquakes before 1934 AD one over a span of 1223 to 1881 AD.

${ }^{2}$ Retrieved from www.drrportal.gov.np, official website of Nepal Disaster Risk Reduction Portal, under Government of Nepal (GoN), data as of 16 July 2015. Also tweeted officially by EarthquakeNepal-MoHA (Twitter handle:

(a)NEoCOfficial) at https://witter.com/NEoCOfficial/status/621649889047347201/photo/1 (district map of those dead by Nepal Earthquake) and https://twitter.com/NEoCOfficial/status/621645187366850560/photo/1 (district map of those injured).

${ }^{3}$ As of 14 November 2015 at 6:19 pm, retrieved from www.seismonepal.gov.np, official website of National Seismological Centre (NSC), GoN.
} 
few minutes after). It also triggered Himalayan avalanches at Mount Everest and landslides at various parts of Nepal making the disaster deadlier, and rescue and relief efforts more challenging.

\section{Heritages Lost Forever}

The Gorkha-earthquake proved disastrous for many heritage sites, affecting structures and ancient settlements of Kathmandu, Bhaktapur, Lalitpur, Sankhu, Bungamati, Pangaand many others, including those enlisted in the UNESCO World Heritage Site list ${ }^{5}$. Several temples in the valley completely collapsed - Kāșthamaṇdapa, Mājudevala, Kāmadeva, Trailokya-Mohana Nārāyana, RādhāKrṣna, Nārāyaṇa temple (Hanumāndhoka Palace), Anantapur, Śāntipur (Svayambhu), Jangahiranya Nema Nārāyaṇa (Tripureśvara), Jalavināyaka, Jaiśídevala in Kathmandu district, Cāra-Nārāyaña, Hariśañkara, Maṇimaṇdapa pātī (Lalitpur Palace), Jagata-nārāyaṇa (Sankhamul), Macchindranāth, Bhairavanāth (Bungamati) in Lalitpur district, Vatsalādevī, Phasī-devala, Kedāranātha (Bhaktapur Palace), Lakmi Nārāyaṇa, Ga-Mahādeva (Changu) in Bhaktapur district - and many others were left severely damaged categorized under "partially collapsed" (95) and "partly damaged" (493) ${ }^{6}$. Also completely collapsed

\footnotetext{
${ }^{5}$ For the full list, see: whc.unesco.org/en/list.

${ }^{6}$ A list issued by Department of Archaeology (DoA) provides the following statistics:
} 
were Tripurāsundarī temple (Dolakha), Taleju temple (Nuwakot), Gorkhā Palace, TetāngchusāngGumbā (Mustang) outside the valley. Most number of heritages in Kathmandu were lost (229), followed by that in Lalitpur (121) and Bhaktapur (73) - a combined total of 423 heritage loss inside the valley alone. Considering such a huge, irreplaceable loss of precious heritages, historian Purushottam Lochan Shrestha states:

We have lost most of the monuments that had been designated as World Heritage Sites in Kathmandu, Bhaktapur and Lalitpur. They cannot be restored to their original states. ${ }^{7}$

\begin{tabular}{|c|c|c|c|c|c|c|}
\hline $\begin{array}{l}\text { S. } \\
\text { N. }\end{array}$ & City & $\begin{array}{l}\text { Total } \\
\text { Heritages } \\
\text { Affected }\end{array}$ & Collapsed & $\begin{array}{l}\text { Partially } \\
\text { Collapsed }\end{array}$ & $\begin{array}{l}\text { Partly } \\
\text { Damaged }\end{array}$ & Remarks \\
\hline 1. & Kathmandu & 229 & 43 & 50 & 136 & \multirow[t]{4}{*}{$\begin{array}{l}\text { Most damages in a } \\
\text { district }\end{array}$} \\
\hline 2. & Lalitpur & 121 & 13 & 20 & 88 & \\
\hline 3. & Bhaktapur & 73 & 20 & 10 & 43 & \\
\hline \multicolumn{2}{|c|}{ Kathmandu Valley } & 423 & $\underline{76}$ & $\underline{80}$ & 267 & \\
\hline 4. & Gorkha & 35 & 8 & 5 & 22 & \multirow{2}{*}{$\begin{array}{l}\text { Epicenter of major } \\
\text { earthquake dated } 25 \\
\text { April } \\
\text { Epicenter of } \\
\text { numerous } \\
\text { aftershocks following } \\
\text { Gorkha } \text { earthquake }\end{array}$} \\
\hline 5. & Dolakha & 29 & 9 & 0 & 20 & \\
\hline & Total & 721 & 133 & 95 & 493 & All over Nepal \\
\hline
\end{tabular}

* Credit to Er. Om D Rajopadhyaya for sharing this table by DoA, GoN.

${ }^{7}$ In an interview for The Kathmandu Post, quoted by The Nation (2015 April 26, $6: 18 \mathrm{pm}$ ). Retrieved from www.nationmultimedia.com/breakingnews/Historicalmonuments-lost-forever-30258805.html on 14 December 2015 Monday. Bangkok: The Nation Multimedia. 
For the purpose of this article, I focus on two major and popular structures of Kathmandu, viz. Käșthamaṇdap (henceforth Kasthamandap) and Dharaharā (henceforth Dharahara). I fully acknowledge that these two heritages only do not entirely represent the essence of all other heritages that were lost to the Gorkha-earthquake.

Kasthamandap and the Name 'Kathmandu'

The Kathmandu city derives its name from Kasthamandap, the former being a corrupt of the latter Sanskrit word ' $k \overline{a s s t h a '}$ meaning wooden and 'mandapa' meaning a pavilion or temple as well. The temple of Kasthamandap, befitting its name, is a master-piece of traditional architecture and exquisitelycarved wooden arts. Risal (2015:1) describes it as "the largest structure ever built in the traditional triple-tiered roof style... [with large ground floor space] until the eighteenth century". Thapa (1968:42) describes the structure as:

... a temple ... on a square plinth, built of bricks, that measures $65 \mathrm{ft} .11 \mathrm{in}$. on each side[,] ... the superstructure resting on the single-terraced plinth ... supported by four massive wooden pillars of square crosssection, that arech [arch?] upto the ceiling of the roof. Two successive floors of receding sizes rest on the basic pillars. The main deity enshrined in the sanctum sanctorum at the 


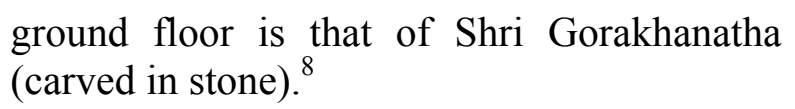

Regarding the construction of this wooden pavilion, Wright's vamśa âvali (1877:211) presents the following account in 1595 AD (NS 715) ${ }^{9}$ :

In his [Lakshmi-narasinha Malla's] reign, on the day of Machchhindra-nātha's Lagan-jātrā ... Kalpa-briksha (the tree of Paradise) was looking on in the form of a man, and, being recognized by a certain Bisēta, was caught by him, and was not released until he promised the Bisēta that ... he would be enabled to build a satal (pātī) with the wood of a single tree.

Local lore claims that the temple was built of wood of a single tree, granted by heavenly Kalpabriksa himself. The wish was fulfilled on the fourth day to build 'Madu-satal' ${ }^{10}$, but the temple "was not consecrated, because the Kalpabrikșa had told the Bisēta that, if it were, the wood would walk away."

\footnotetext{
8 Thapa (1968:39) refers this as Loyīpāda Siddha, while Pant (2015a) recognizes it as $L \bar{u} \bar{\imath} p \bar{a}$, referring to a monograph entitled 'Śriñathatīrthāvalī' compiled by the Rājā of Jodhpur, Mānasingh.

${ }^{9}$ Pant (2015a) adds a line "This was constructed in NS 715" from the folio 126 of MS in the collection of University of Cambridge. But an English version of Wright (1877) in my collection, unfortunately, does not have this line.

${ }^{10}$ Wright (1877:211). The name is popular as Maru sattal or Kasthamandap now.
} 
(Wright, 1877:211). In view of this vamiśâvalī, commonly, and mistakenly, ${ }^{11}$ many consider this sattal to date back only to Lakșmī-Narasimha Malla's reign. Pant (2015a), however, disagrees in the following points:

1. The reign of Lakșmi-Narasimha Malla dates from 1621AD (NS 741) $)^{12}$ to $1641 \mathrm{AD}$ (NS 761) ${ }^{13}$, which does not match the afore-mentioned date of $1595 \mathrm{AD}$ (NS 715). Historically, the validity of this date 1595 $\mathrm{AD}$ (NS 715) is thus hereby nullified.

2. A total of 15 evidences that Kasthamandap existed before the reign of Lakșmi-Narasimha Malla has been published in Itihāsa-Samiśodhanako PramānaPrameyaby Vajracharya (ed.) in $1962 .{ }^{14}$ Among them, the very first mention of Kasthamandap ${ }^{15}$ as research till date suggests, has been found in an MS entitled "Nama-sangiti" copied in 1143 AD (NS 263) during the reign of Narendra-deva II (regnal year: 1140 1146 AD).

${ }^{11}$ See: Pant (2015a) for details.

${ }^{12}$ Pant (2015a) cites Tiwari, Ramji et.al. (1964). Eitihāsika-Patrasangraha Vol. II. Nepal Cultural Council. p. 1-2. Slusser (1982), however, approximates this date to $1619 \mathrm{AD}$.

${ }^{13}$ Ibid cites Vajracharya, Dhanavajra. (Ed.). (1962). Itihāsa-Samśodhanako Pramāna-Prameya. Lalitpur: Jagadamba Publications. p. 81.

${ }^{14}$ Also enlisted by Thapa (1968:37-38).

${ }^{15} c f$. Thapa (1968:41) and Risal (2015:4). 
In addition, Risal (2015:4) cites Mary Slusser and Gautama Vajracharya (1974) to have discovered an MS AstasahasrikaPrajnaparamita with a colophon dating it to 1090 AD (NS 210) in possession of a local guthi associated to Kasthamandap. However, he laments that "it was not made available to the authors [Slusser and Vajracharya] for more than a brief perusal" (Risal, 2015:4). Nevertheless, on basis of what Slusser and Vajracharya state, Risal (2015:10) asserts:

\begin{abstract}
Kasthamandap was at least 900 years old and possibly more than a thousand, at the time of the 2015 earthquakes. It was therefore the oldest building in Kathmandu and anywhere in the entire surrounding Valley. It was also the largest traditional building.
\end{abstract}

A recent excavation campaign by a team of Nepalese and foreign archaeologists co-led by Professor Robin Coningham from Durham University, UK, Kosh Prasad Acharya (former Director-General of DoA) and Ram Bahadur Kunwar (Head of Excavation Branch, DoA) found that the temple was constructed in the $8^{\text {th }}$ century, around 400 years earlier that it was traditionally thought (Neupane, 2016).

The large wooden pavilion was also used as a rest-house for traders through the city, and the surrounding Maru tole has for centuries been a popular market-place. "Kasthamandap occupies a central location in Kathmandu valley, at the intersection of two ancient towns known as Koligrama and Daksina (south) Koligrama (and later as Yambu and Yangal). Moreover, Kasthamandap sits squarely at the crossroads of 
the ancient trade route that connected India with Tibet and the principal North-South road of Kathmandu." (Risal, 2015:2). A historic water-color painting by British surgeon at British Residency in Kathmandu, Henry Ambrose Oldfield, in the 1860 s during Jung Bahadur's rule, reproduced in Risal (2015:2), also supports the claim.

With phonetic similarities between the two names, it is clear that Kasthamandap, as "an important shrine in the [social and cultural] life" (Thapa, 1968:43) of the ancient and medieval Kathmandu, "lend its name to the locality that grew around it, including the royal palaces" (ibid.) and subsequently the name "gradually acquired a much wider connotation with the passage of time" (ibid.). Thapa (1968:43) adds:

[A]s the original city should have been small, with the temple and palace as the central nucleus, it is reasonable to extend the application as well as applicability of the name of the royal city to the localities that grew up around it .... Thus it was the literary form of the name of the most important wooden pavilion that gradually ... [grew and] encompassed (1) the shrine (2) the locality and (3) the capital in gradual progression. 
My focus here is that the Kasthamandap is a public heritage with a social, cultural and economic dependence of a large group of locals, especially from the southern half of the city. This heritage is one of the oldest ones known in the ancient city and was still in public use up to the time of its collapse.

\section{The Kasthamandap Collapse}

On the day of the earthquake on 25 April, a local financial institution, by the name of Nimbus Savings and Credit Cooperative, had organized a blood-donation camp inside Kasthamandap. Altogether 54 people were reportedly "preparing to take a group photograph when the ground beneath them started shaking and brought down the ... temple, killing ten." ${ }^{16}$ One survivor, Amit Awale, shares the following account:

Everything and everyone seemed to be moving. Bricks and mud started falling down ... nearby temples began going down one by one. $^{17}$

\footnotetext{
${ }^{16}$ Nepal Samacharpatra (2015) published in Nepali Times (No. 757). The death toll has risen to 45 afterwards (and probably more?), as rescue efforts continued days after the quake (Pokhrel, 2015:56).

${ }^{17}$ Ibid.
} 
With unavailability of any footages of the area, the understanding of the collapse depends on stories of the survivors and accounts of eye-witnesses. Another survivor, Laxman Ranjit, 30 of Chikanmugal, Kathmandu and also a weight-lifting national champion, shares this account during blood donation:

First, Kasthamandap and the earth started shaking slightly... I got [deep] into Kasthamandap thinking it safe. Those inside started running out ... Taking out the needle, I carried my son outside. Nilu [his wife] remained in. I was only few steps outside when the Kasthamandap collapsed with a large sound. I had never expected it. ${ }^{18}$

There were no close-circuit cameras installed at this place and, thus, our (and media) knowledge of its collapse are based on these stories. It, however, had many stories to unfold, which were much later (almost after more than a couple of years of the Gorkha-earthquake) recognized and covered in national media. But these materials do not come under the purview of this article.

${ }^{18}$ Ghising. (2015). Translated by the author. 


\section{Post-Earthquake Media Coverage of Kasthamandap}

For the purpose of this article, I have analyzed the contents of five national dailies after the Gorkha-earthquake, viz. Annapurna Post, Nagarik Dainik, Kantipur, Naya Patrika and Rajdhani to see the coverage of Kasthamandap. The following table enlists few of the news, opinion articles and/or photographs regarding Kasthamandap used for this study. It also reflects the coverage pattern of the historic Kasthamandap temple by the Nepali national dailies:

Figure 1: Table showing media coverage of Kasthamandap

\begin{tabular}{|c|c|c|c|c|c|}
\hline $\begin{array}{l}\text { Newsp } \\
\text { aper }\end{array}$ & Date & $\begin{array}{l}\text { Byline/ } \\
\text { Writer }\end{array}$ & $\begin{array}{l}\text { News } \\
\text { Headline }\end{array}$ & $\begin{array}{l}\text { Descriptio } \\
\text { n }\end{array}$ & Remarks \\
\hline $\begin{array}{l}\text { Annapu } \\
\text { rna Post }\end{array}$ & $\begin{array}{l}11 \\
\text { Jestha } \\
\text { (25 } \\
\text { May) }\end{array}$ & $\begin{array}{l}\text { Gopikrish } \\
\text { na } \\
\text { Dhungana }\end{array}$ & $\begin{array}{l}\text { Dharaharā } \\
\text { durustai } \\
\text { banāine } \\
\text { [Dharahara to } \\
\text { be rebuilt } \\
\text { exact] }\end{array}$ & $\begin{array}{l}\text { News } \\
\text { value due } \\
\text { to a } \\
\text { minister's } \\
\text { visit }\end{array}$ & $\begin{array}{l}\text { Only a } \\
\text { reference } \\
\text { to } \\
\text { Kasthama } \\
\text { ndap }\end{array}$ \\
\hline $\begin{array}{l}\text { Nagarik } \\
\text { Dainik }\end{array}$ & $\begin{array}{l}13 \\
\text { Baisakh } \\
\text { (26 } \\
\text { April) }\end{array}$ & $\begin{array}{l}\text { KP } \\
\text { Dhungana }\end{array}$ & $\begin{array}{l}820 \text { ko mrtyu } \\
\text { puști, arbaũ } \\
\text { kșati, uddhar } \\
\text { jārī, vivaraṇa } \\
\text { āuna bắkī } \\
{[820 \text { death }} \\
\text { confirmed, } \\
\text { billions loss, } \\
\text { rescue }\end{array}$ & $\begin{array}{l}\text { Hard } \\
\text { news, } \\
\text { double- } \\
\text { line } \\
\text { banner } \\
\text { headline, } \\
\text { details } \\
\text { relating to }\end{array}$ & $\begin{array}{l}\text { Includes } \\
\text { reference } \\
\text { to } \\
\text { Dharahara } \\
\text { and } \\
\text { Kasthama } \\
\text { ndap }\end{array}$ \\
\hline
\end{tabular}




\begin{tabular}{|c|c|c|c|c|c|}
\hline & & & $\begin{array}{l}\text { continued, } \\
\text { details yet to } \\
\text { come] }\end{array}$ & $\begin{array}{l}\text { cover } \\
\text { story }\end{array}$ & \\
\hline & & $\begin{array}{l}\text { Prakash } \\
\text { Timalsina }\end{array}$ & $\begin{array}{l}\text { Kāṭhmāṇ̣u } \\
\text { upatyakākā } \\
\text { adhikāmsśa } \\
\text { sampadā } \\
\text { dhale [Many } \\
\text { heritages in } \\
\text { Kathmandu } \\
\text { Valley } \\
\text { collapsed] }\end{array}$ & $\begin{array}{l}\text { Hard } \\
\text { news, } \\
\text { details } \\
\text { relating to } \\
\text { cover } \\
\text { story }\end{array}$ & $\begin{array}{l}\text { Only a } \\
\text { reference } \\
\text { to } \\
\text { Kasthama } \\
\text { ndap }\end{array}$ \\
\hline $\begin{array}{l}\text { Kantipu } \\
r\end{array}$ & $\begin{array}{l}9 \\
\text { Jestha } \\
\text { (23 } \\
\text { May) }\end{array}$ & $\begin{array}{l}\text { Raju } \\
\text { Ghising } \\
\text { (with a } \\
\text { photo by } \\
\text { Kaushal } \\
\text { Adhikari) }\end{array}$ & $\begin{array}{l}\text { 'Āfailāi pardō } \\
\text { thāhā hudo } \\
\text { raheca' } \\
\text { ["We know } \\
\text { only when it } \\
\text { befalls on us."] }\end{array}$ & $\begin{array}{l}\text { Soft news, } \\
\text { story of a } \\
\text { survivor }\end{array}$ & \\
\hline \multirow{2}{*}{$\begin{array}{l}\text { Rajdhan } \\
\text { i }\end{array}$} & $\begin{array}{l}13 \\
\text { Baisakh } \\
\text { (26 } \\
\text { April) }\end{array}$ & $\begin{array}{l}\text { Dabbu } \\
\text { Chhetri }\end{array}$ & $\begin{array}{l}\text { Aitihasik } \\
\text { dharohara } \\
\text { dhvasta } \\
\text { [Historic } \\
\text { monuments } \\
\text { devastated] }\end{array}$ & Hard news & $\begin{array}{l}\text { Only a } \\
\text { reference } \\
\text { to } \\
\text { Kasthama } \\
\text { ndap }\end{array}$ \\
\hline & $\begin{array}{l}23 \\
\text { Jestha } \\
\text { (7 June) }\end{array}$ & $\begin{array}{l}\text { Nabin } \\
\text { Luitel }\end{array}$ & $\begin{array}{l}\text { Pahilekai } \\
\text { svarūpamā } \\
\text { Kāșțhamaṇḍa } \\
p \quad \text { banne } \\
\text { [Kasthamanda } \\
p \text { to be }\end{array}$ & $\begin{array}{l}\text { Hard } \\
\text { news, } \\
\text { reconstru } \\
\text { ction } \\
\text { attempt }\end{array}$ & \\
\hline
\end{tabular}




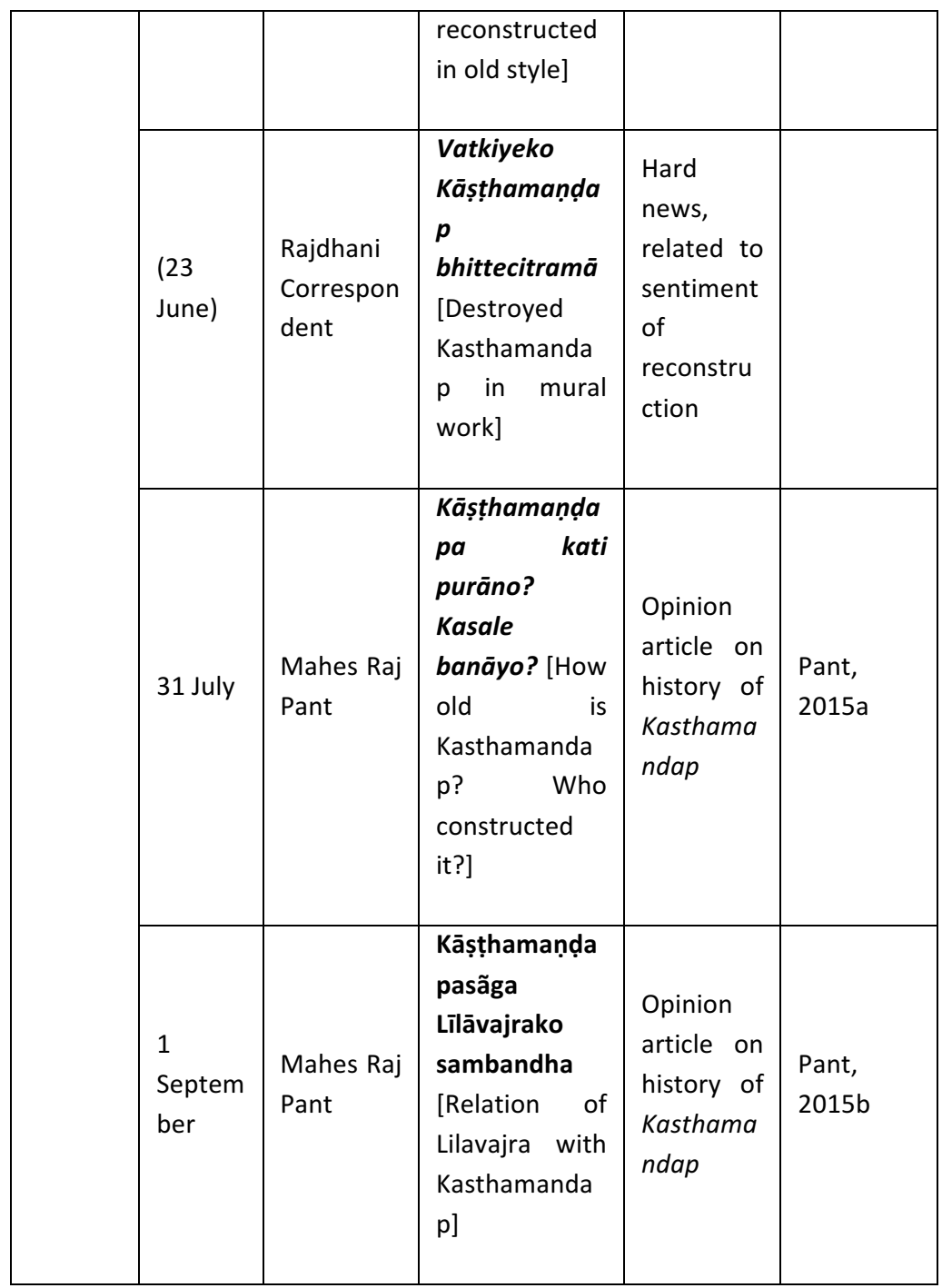

* All years in 2072 BS or 2015 AD. 
The scholarship of Nepali media on Kasthamandap was much limited only to what Wright's vamsíâvali and local lore states - that it was constructed of the wood of a single tree - and that it gave Kathmandu its name. But the very entry in the vamiśavalì has already been questioned by Pant (2015a) as stated above. Only two articles on history of Kasthamandap have come into light (Pant, 2015a and 2015b). In addition, Sukrabar weekly (editor: Rajan Nepal) dated 15 May or 1 Jestha published by Nepal Republic Media has an article by Dinesh Raj Pant on "Kāṣțhamaṇụapa (Marusattala)" (p. 8), reflecting the claim that unlike popularly believed, the structure existed way before the reign of Lakșmi-Narasimha Malla from 1621 to 1641 AD.

The story of the actual collapse of Kasthamandap is only available via the version of a survivor, Laxman Ranjit, ${ }^{19}$ who lost his wife at blood-donation and himself suffered leg injury. Additionally, a story in Nepali Times (not included as a sample for this study, but cited elsewhere due to lack of other documented evidences) has a story of another survivor, but he fails to give a detailed account of the collapse of the age-old structure. A commoner's observation of the large central pillars that supported the colossal structure of the Kasthamandap that were left unguarded at the Big Bell, Kathmandu shows the breaking and decaying of tongue of the pillar, causing the structural failure.

${ }^{19}$ Refer to footnote \#18. 


\section{The Dharahara Tower: New Polity of Modern Nepal}

As a popular landmark of Kathmandu, Dharahara is more known to all than other structures of traditional inner cities. The Dharahara is a nine-storey tower built in 1832 by Mukhtiyār Bhimsen Thapa (1775 - 1839 AD). The tower has a spiral staircase of 213 steps, with a balcony at eight-floor and a 5.2 meter (17 ft.) bronze mast on the roof. Two Dharaharas actually existed during Bhimsen Thapa's time, called Maharani Dharahara and General Dharahara. The former was constructed in the name of Queen Lalit Tripurasundari (1794 - 1832 AD, regent rule: 1806 - 1832 $\mathrm{AD}$ ) and was, by name, taller and wider than the latter, built in the name of Bhimsen Thapa. The devastating earthquake of 1834 AD saw the collapse of General Dharahara, while Maharani Dharahara survived with need for repairs. A century later, again in the earthquake of 1934 AD, the Maharani Dharahara collapsed and was rebuilt by Juddha Shumsher JBR (regnal years: 1932 - 1952); this later became popular as Bhimsen Stambha (Bhimsen column, or more popular Dharahara). ${ }^{20}$

Constructing tall columns had been popular in traditional architecture of the valley as well; reference can be seen from that at Changu Narayan temple ${ }^{21}$, the oldest temple in Nepal or at all medieval royal palaces and even those in the Shah rule (e.g. at Guhyeśvari $)$ - all aimed at depicting the height of power of those atop. Likewise, Dharahara named after

\footnotetext{
${ }^{20}$ op.cit. Dhungel (2015).

${ }^{21}$ I refer here to the Garuda column of Changu Narayan, of which only a small stump now remains and the Garuda icon, of course.
} 
Queen Lalit Tripurasundari and Bhimsen Thapa marked their power in the modern Nepal for over three decades.

The major idea is that Dharahara was a very late heritage and symbolized elite groups — those in power, without any cultural-economic relation with the locals. The Kathmandu Metropolitan City (KMC) opened it to general public taking a specific entry fee and was maintained by an external partner, Sidewalkers Pvt. Ltd., with whom the Kathmandu Metropolitan city had a Memorandum of Understanding to manage the area. It was later, thus, more commercial than cultural.

\section{The Fall of the Tower}

In Nepali, Dharahara stands for tall tower. Many papers almost synonymized Dharahara with another phoneticallysimilar Nepali word 'dharohara', meaning somewhat close to heritage. Most papers (including those taken as sample in this study) have also used Dharahara to represent the idea of heritage overall.

It fell for the first time in $1834 \mathrm{AD}$ earthquake, only two years after its construction, and collapsed to $1934 \mathrm{AD}$ earthquake. Later, Juddha Shumsher JBR repaired it, but it fell to the recent 2015 earthquake. Some reports also accused that reconstructions were not made in time and properly ("Bhūkampale 5 saya 81 sampadāmā kṣati" by Rajdhani dated 17 May). Its fall to 1834 earthquake, however, clearly marked Bhimsen Thapa's fall from power, especially after the death of the regent Queen. Historian Ramesh Dhungel adds: 
After the fall of General Dharahara (of Bhimsen Thapa), his power in the rule started decreasing. Thus, the Dharahara named after him could not be reconstructed at that time. ${ }^{22}$

Many versions of the fall from Kasthamandap and other accounts by eye-witnesses have been reported (e.g. "Dharaharāko tuppobāta khasdā pani bẵciyo" by Babita Sedhai in Annapurna Post dated 30 April, "Jyāna Jogiyeko Janmadina" by Gopikrishna Dhungana in Annapurna Post dated 23 July and "Dharaharā cāra tukrā vaera dhalyo" by Bijay Chamling in Rajdhani dated 14 May). The weeklyholiday on Saturday added the flow of people inside the tower. Some videos of the fall from Dharahara also went viral in YouTube ${ }^{23}$ as well. Overall, we have more documentation of the fall of Dharahara as compared to that of Kasthamandap.

The following table gives a comparison of Dharahara and Kasthamandap; the figures are for representational purpose only and do not exact in measurements.

\footnotetext{
${ }^{22}$ Historian Ramesh Dhungel speaks for Naya Patrika Dainik (2015).

${ }^{23}$ See: "Dharahara Falling Live Nepal Earthquake 2072/2015"

https://www.youtube.com/watch?v=Qwr3bIjnzPo.
} 
Figure 2: Comparison of Dharahara and Kasthamandap Coverage (Images for representational purpose only)

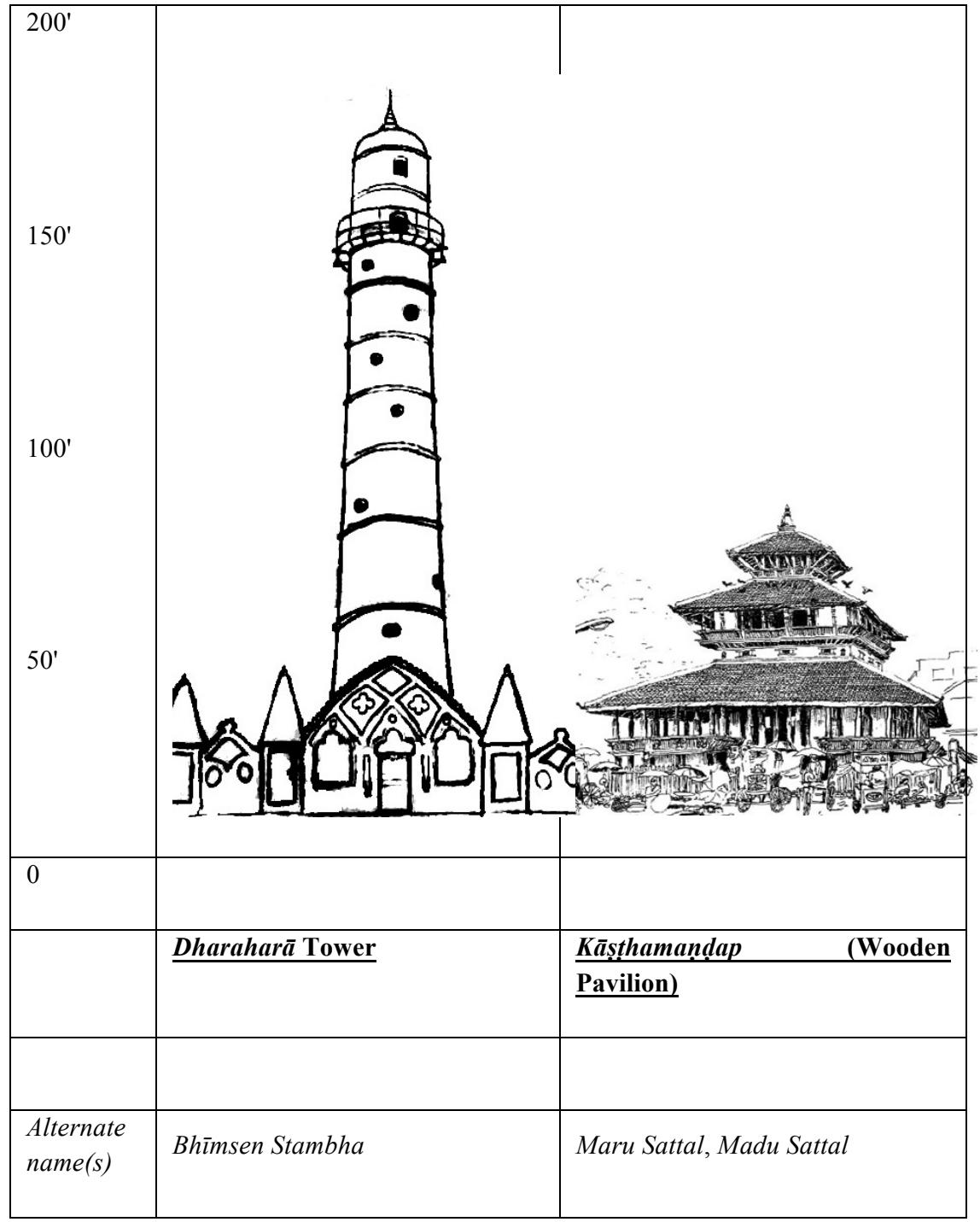




\begin{tabular}{|c|c|c|}
\hline Type & Tall tower / minaret & Public building \\
\hline $\begin{array}{l}\text { Architectu } \\
\text { re }\end{array}$ & Mughal style & Traditional pagoda-style \\
\hline Storey & 9 & 3 \\
\hline Height & $203^{\prime}(61.88 \mathrm{~m})$ & $65^{\prime} 4 "$ \\
\hline History & 1832 by Bhimsen Thapa & c. $8^{\text {th }}$ century \\
\hline Purpose & $\begin{array}{l}\text { Military watch-tower, } \\
\text { information-dissemination }^{24}\end{array}$ & $\begin{array}{l}\text { Public / religious / cultural, } \\
\text { market-place }\end{array}$ \\
\hline $\begin{array}{l}\text { Re- } \\
\text { constructi } \\
\text { on }\end{array}$ & After 1934 earthquake & $\begin{array}{l}\text { Several times, including recent } \\
\text { ones }\end{array}$ \\
\hline Fall & 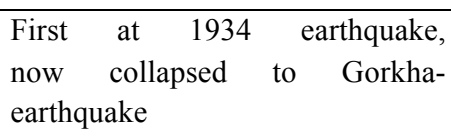 & $\begin{array}{l}\text { Previously undocumented; now } \\
\text { completely collapsed }\end{array}$ \\
\hline $\begin{array}{l}\text { No. of } \\
\text { affected } \\
\text { people }\end{array}$ & $150^{25}$ & $54^{26}$ \\
\hline $\begin{array}{l}\text { Death } \\
\text { toll }^{27}\end{array}$ & 60 & 45 \\
\hline
\end{tabular}

\footnotetext{
${ }^{24}$ Nepal (2015)

${ }^{25}$ Dhungana (2015). He reports 240 tickets had been issued before the incident occurred.

${ }^{26}$ NepaliTimes (2015)

${ }^{27}$ Pokhrel (2015:56)
} 


\begin{tabular}{|l|lr|lr|}
\hline $\begin{array}{l}\text { Present } \\
\text { status }\end{array}$ & $\begin{array}{l}\text { Only a 33' }(10 \mathrm{~m}) \text { stump now } \\
\text { remains, } \\
\text { commenced }\end{array}$ & $\begin{array}{l}\text { reconstruction } \\
\text { reconstruction commenced }\end{array}$ & $\begin{array}{l}\text { Completely } \\
\text { remded, }\end{array}$ \\
\hline
\end{tabular}

\section{Post-Earthquake Media Coverage of Dharahara}

Similar to the previous one on the coverage of Kasthamandap, I have analyzed the contents of the afore-mentioned five major national dailies after the Gorkha-earthquake, to see the coverage of Dharahara. The following table shows quantitatively a large coverage of less than two centuries-old Dharahara in various aspects.

Figure 3: Table showing the media coverage of Dharahara

$\begin{array}{llll}\text { Newspape } & \text { Byline } & \text { Date } & \text { Writer } \\ \text { r } & \text { Wews Headline }\end{array}$

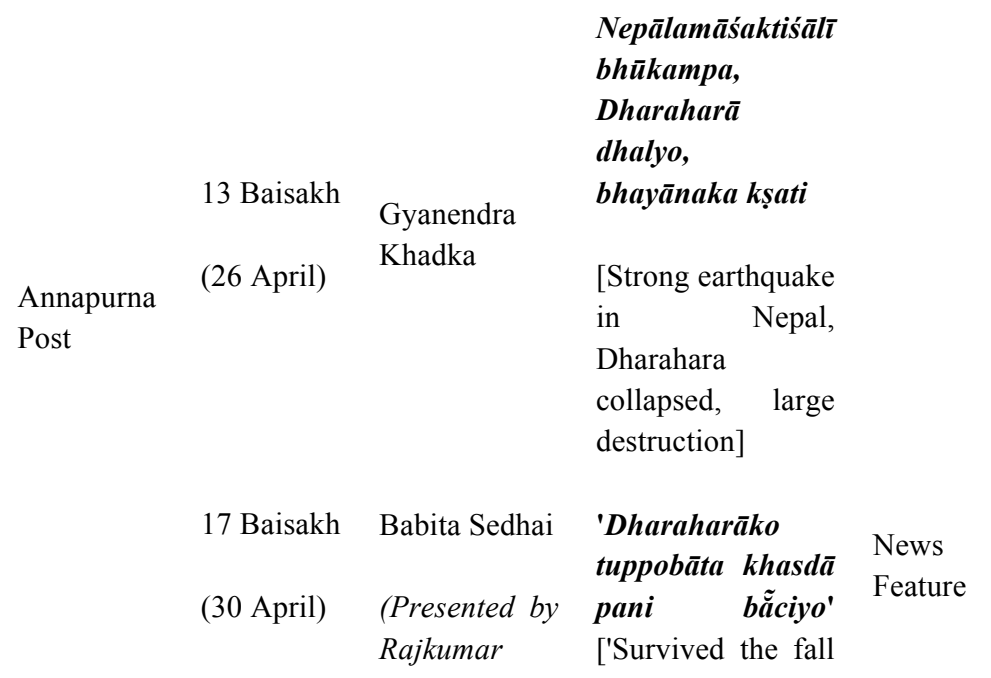




$\begin{aligned} & \text { Dikpal and from the top of } \\ & \text { Kirtan Dharahara'] } \\ & \text { Adhikari) }\end{aligned}$

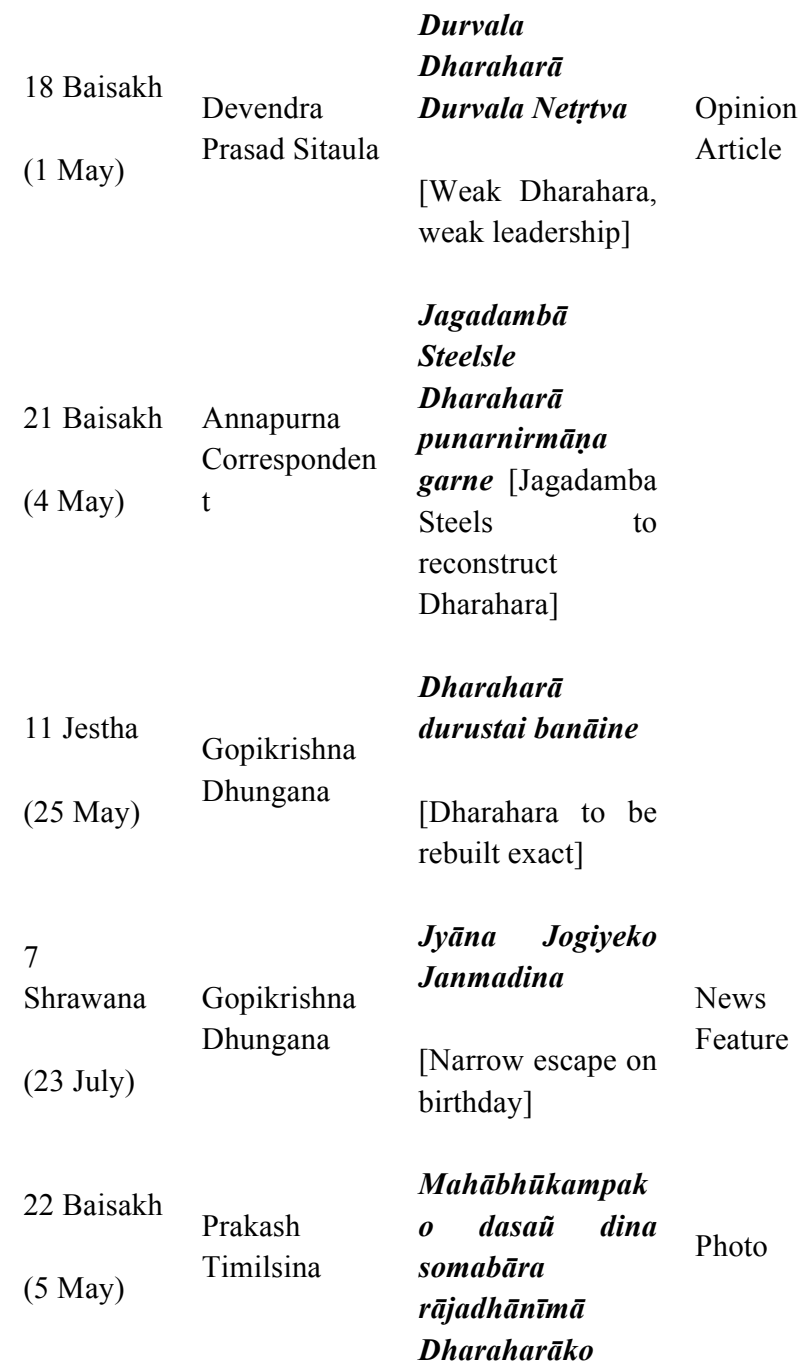




\author{
bhagnāvaśeṣa \\ herdai \\ sarvasadhārana \\ [People watch the \\ ruins of Dharahara \\ on $10^{\text {th }}$ day of \\ earthquake on \\ Monday]
}

22 Bhadra

Nagarik

Dainik Dharahara]
(8

Rupa Joshi

September

)

13 Baisakh

(26 April)

22 Baisakh KP Dhungana

KP Dhungana

[A wish to make

(5 May)
820 ko mrtyu puṣti, arbaĩ kṣati, uddhar jārī, vivaraṇa āuna bă $\boldsymbol{k} \overline{\boldsymbol{\imath}}[820$ deaths confirmed, billions loss, rescue continued, details yet to come]

Dharaharā banāune rahara

Soft news

Opinion

article

Cover

Feature

[Dozens shocks, thousands injured]

Dharaharālāịthut

[Let Dharahara be

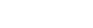

Darjanaũ dhakkā, hajāraũ hatāhata

,




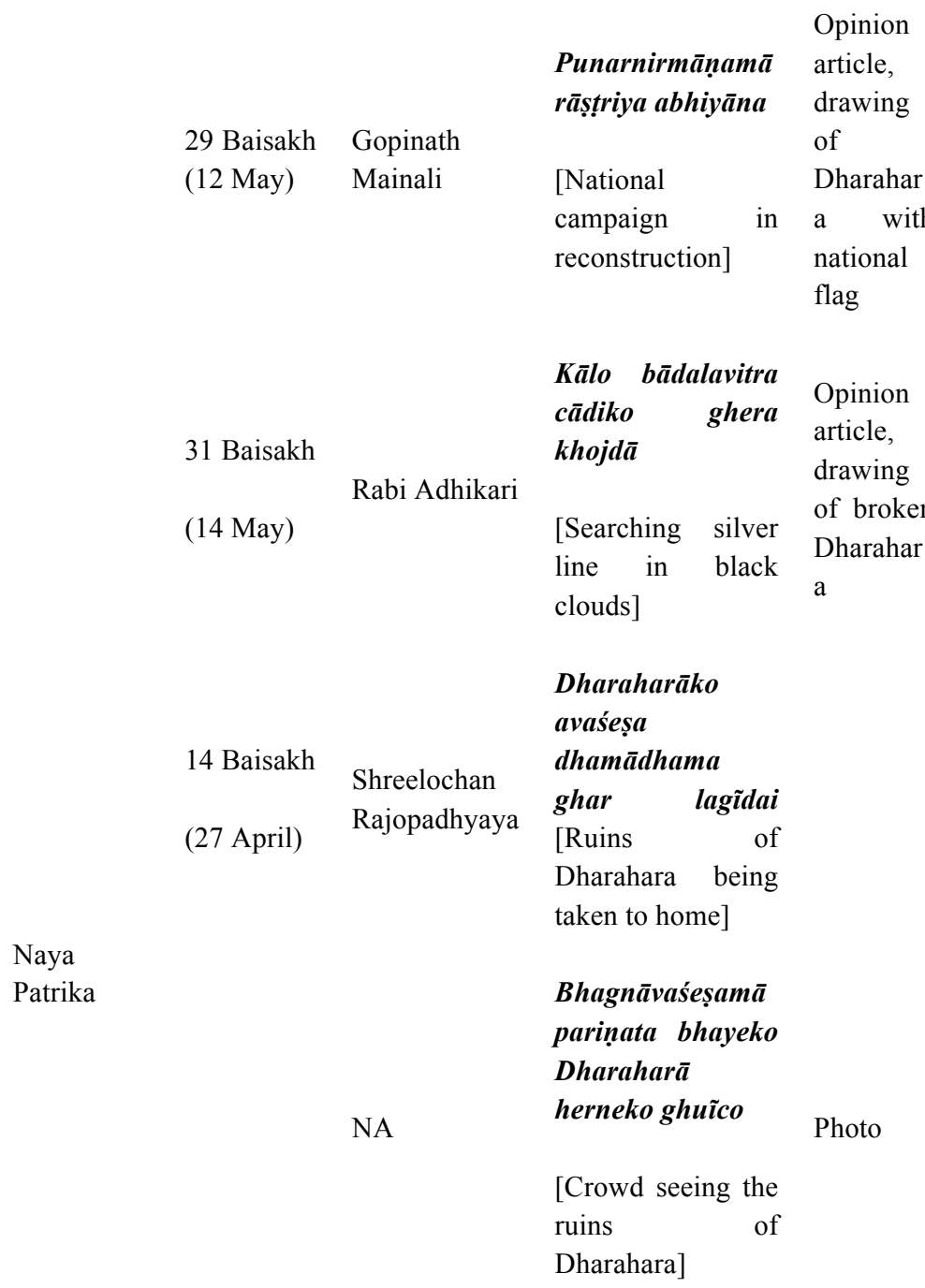




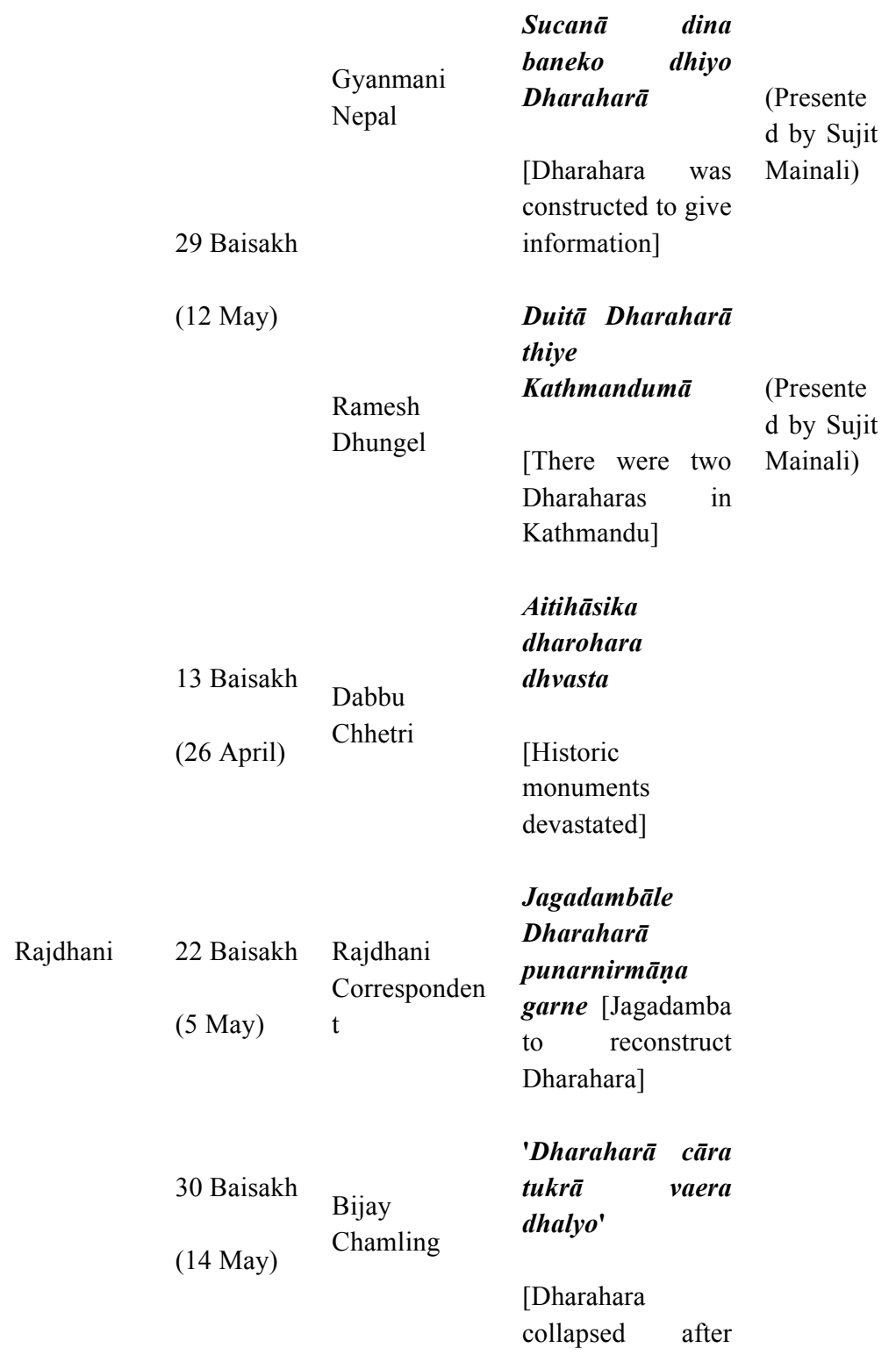




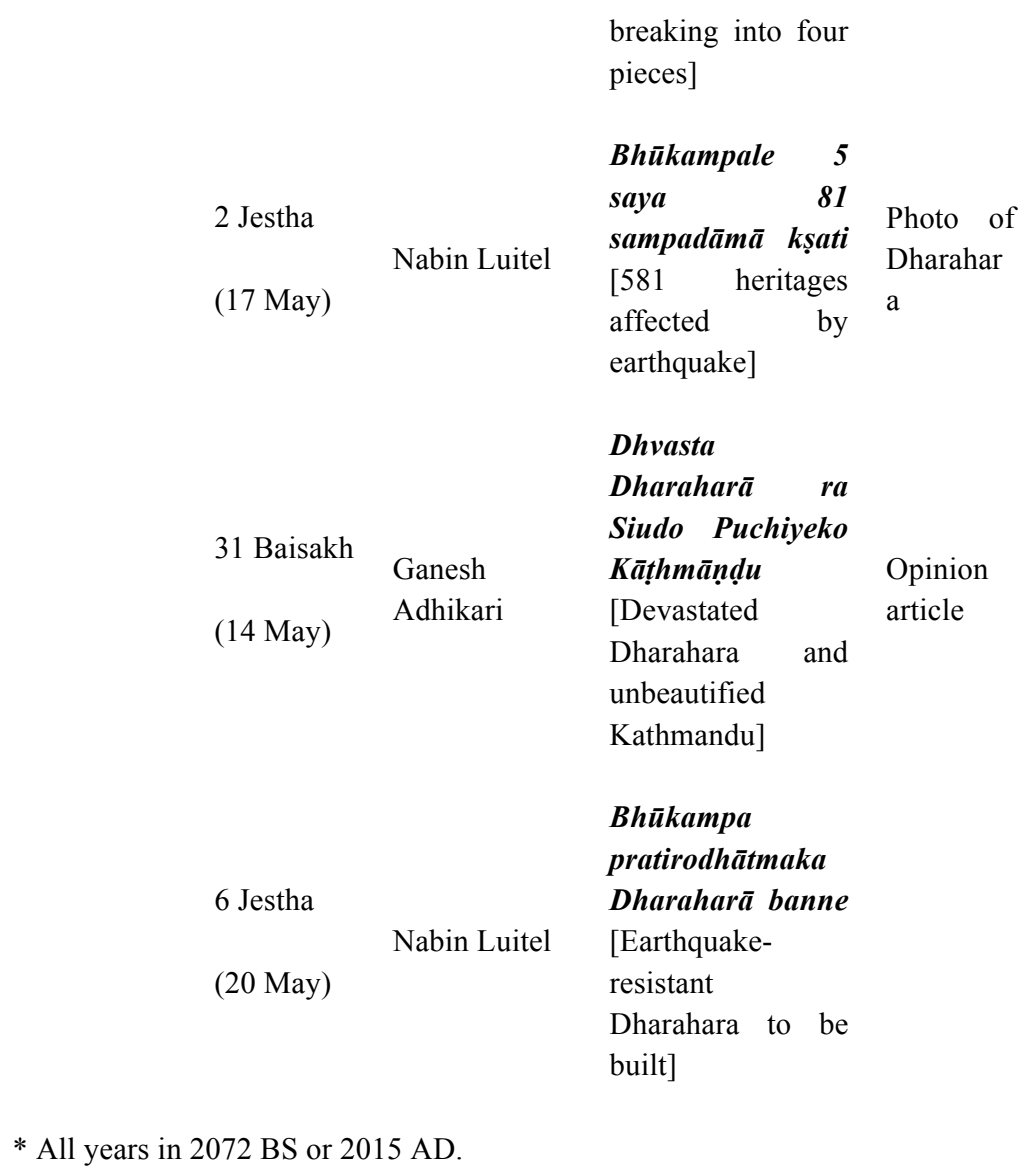

The table shows that Dharahara found comparatively a larger space than any other heritages. It was portrayed as the ornament of Kathmandu (in Ganesh Adhikari's opinion piece, see Appendix 3), as the representation of all other historic monuments that fell to the earthquake (in the news, feature 
and photos by almost all media, see Appendix 3), as a subject of emotional appeal (by Kantipur, see Appendix 4) and as a symbol of national unity (see Appendix 4). Slogans of rising back from the disaster also included the portrayal of Dharahara for almost all Nepali national newspapers.

\section{Attempts at Reconstruction}

News have been disseminated announcing the undertaking of reconstruction of Dharahara, but almost no such news of Kasthamandap was seen in Nepali national dailies. Dharahara, as popular landmark of the city, received due importance with commitments of reconstruction by government ("Bhūkampa pratirodhātmaka Dharaharā banne" by Nabin Luitel in Rajdhani dated 20 May). Even the corporate sectors were interested in its reconstruction. One such included that by Jagadmba Steels, which brought mixed reactions - some reacted that Dharahara should be left as it is (e.g. Rupa Joshi in Kantipur, 8 September, p. 7), while some complained no corporate houses should be allowed to use Dharahara for their advertisements.

The reconstruction attempt at Kasthmandap received almost none media attention. Far the mainstream media interest, alternative ways were initiated by the locals only. For a campaign on rebuilding Kasthmandap, Risal started a website www.rebuildkasthamandap.com in an attempt to bringing it back. Risal (2015) is also concerned in finding the lost inscriptions to save history, especially those attached to the temple woods. Some local organizations also announced Campaign for Reconstruction of Kasthamandap, while 
Kathmandu Metropolitan City (KMC) also took few steps for the cause. Currently, a team of archaeologists are undertaking excavation works at the devastated site. An artistic representation of Kasthamandap was made in mural art at Babarmahal, Kathmandu by Hatemalo Campaign and was inaugurated by Chief Secretary Lilamani Poudel on 22 June 2015. A modelled 3-D design of Kasthamandap was prepared by artist Hira Ratna Brahmacharya and was handed to the KMC. Meanwhile, Ar. Wolfgang Korn also handed over his structural drawings on 7 November 2015, Saturday that he used for his book (Korn, 1998) asserting its importance to the national identity.

Nonetheless, the attempts at reconstructing Dharahara also used alternative artistic ways. A miniature replica of Dharahara is also placed at a traffic triangle at Sahid Gate, Kathmandu commemorating the tower that is now no exist. Several other replicas were also made at different places of the valley too.

\section{Theoretical Epilogue}

Dharahara found more space in national dailies, symbolic of enormity of the earthquake (as reflected in the photos of the devastated site), and was later reproduced to represent call to rising (e.g. see appendix 4) and to national identity (appendix 5: Nagarik dated 12 May). The tower-structure was portrayed as identity of Kathmandu and entire Nepal; portrayal of Nepal's rising back included Dharahara, an elite heritage of modern times, while public heritages were completely neglected by the mainstream media. 
Ganesh Adhikari's version that Kathmandu lies tearful at the loss of its ornament Dharahara ("Dhvasta Dharaharā ra Siudo Puchiyeko Kāthmānḍu", Rajdhani, 14 May) asserts this single heritage as what matters to the Kathmandu (and subsequently to Nepal). Other heritages that went undamaged or only partially damaged were not in the mainstream media. This too had to take alternative course in the form of a hash tag "\#notallgone" that gained little popularity along this line.

The much-criticized idea of unity in diversity that was enforced during Panchayat regime of King Mahendra (1920 1972, regal years: 1955 - 1972) that gave supremacy to one culture, language and symbol over the other. The Nepali media too was guided by the same idea to give supremacy to Dharahara over all other heritages, no matter however significant they are. Pushing aside the historic, socio-cultural and economic significance of Kasthmandap for the local and all those traders, who once travelled through this ancient open square, the Nepali national media desperately put ahead or enforced Dharahara as a symbol of national identity.

The elite ruler notion can also be seen in the light of ethnic notion, where the ruling-class Brahmin-Chhetri built Dharahara gained supremacy over the now ethnic locallyowned Kasthamandap. The fact that Nepali media itself is owned and operated by majority Brahmin-Chhetri too accounts for this bias. It was the ruling Shah-Thapa class, who built the Dharahara and was later named upon the ruling class, but the story of Kasthmandap is otherwise - it is essentially public and lore has it that it was built by a local Lilavajra (though it is questionable). 
The Foucauldian idea of subjectivation (or subjectivization) comes into play here: the identity is not self-internalized but enforced by various, what Althusser would say, ideological mechanisms. No matter how much local newspapers (mostly in Nepal Bhasa) would assert the essence of Kasthmandap, the identity was shaped for elite tower-structure Dharahara. Technically, both are national heritages, both collapsed and both claimed many lives - both deserve to stand as a symbol of unity and of respect for age-old heritages.

The idea that Nepali media lacked evidences of Kasthmandap, while those of Dharahara were plenty too helped such portrayal. The evidences of Kasthamandap are scattered - the very first evidence dating to $12^{\text {th }}$ century and many others following that have been currently found at Sakya monastery in Tibet (Pant, 2015a). Such biased media reporting and loss of Kasthamandap would also mean loss of a heritage that has survived so centuries, of medieval and of modern Nepal.

As discussed earlier, Dharahara represented a new symbol for modern Nepal during the Shah period, against the traditional Kasthmandap. As a popular heritage of early medieval Nepal, Kasthamandap had represented the identity of the city and even lend the expanding city its name. ${ }^{28}$ This identity-making has been overpowered owing to the dynastical shift, and as the city and in-migration grew more, the new polity shed traditional identity of Kasthamandap, which was once popular as public rest-place. It might be interesting to examine further how the collapse of both these

${ }^{28}$ op.cit. Thapa (1968:43) 
structures - artistic master-pieces of their times - can give symbolic interpretation to the course of history.

A constructivist ${ }^{29}$ national identity of Dharahara in the modern Nepal seems to have followed a nationalistic model, characterized by "national homogeneity under the aegis of ... those in power" ${ }^{30}$, in the post-earthquake context. With government, public and corporate commitments on reconstruction of Dharahara (e.g. "Bhükampa pratirodhātmaka Dharaharā banne" by Nabin Luitel in Rajdhanidated 20 May, "Jagadambā Steelsle Dharaharā punarnirmāna garne" by Annapurna Post dated 4 May and "Jagadambāle Dharaharā punarnirmāṇa garne" in Rajdhani dated 5 May), the step has already been taken. But, nevertheless, people are still divided over what should be prioritized Dharahara (an elite, commercial heritage) or Kasthamandap (a cultural public one).

As Dharahara has been presented as a national symbol for unity, Sitaula (2015) rightly warns:

Dharahara had collapsed to 1934 earthquake, and after mere 82 years it again collapsed. Now if it is to be raised, it must be considered - how powerful and strong it should be. It has other symbolic meanings too. Dharahara must not be raised weak, as national leaders of today. Now Dharahara must nurture strong

\footnotetext{
${ }^{29}$ See: Gellner (1997).

${ }^{30}$ See: Pfaff-Czarnecka (1997).
} 
leadership in symbolic meaning for the nation and for its future.

The above call stands true, even if Kasthamandap shares a similar position.

\section{References}

Althusser, L. ([1970] 1971). "Ideology and Ideological State Apparatuses". Lenin and Philosophy and Other Essays. Brewster, B. (trans.). Monthly Review Press. Retrieved from

www.marxists.org/reference/archive/althusser/1970/ideol ogy.htm.

Dhungel, R. (2015, May 12). "Duitā Dharaharā thiye Kāthmāṇụumā". Naya Patrika Dainik. 9:28. Retrieved from www.enayapatrika.com/2015/05/5722 on 14 December 2015. Kathmandu: Naya Publications Pvt. Ltd.

Foucault, M. (1983). "The Subject and Power". In Dreyfus, H \& Rabinow, P. (eds.). Beyond Structuralism and Hermeneutics. Chicago: University of Chicago Press. pp. 208-226.

Gellner, D. N. (1997). "Ethnicity and Nationalism in the World's Only Hindu State". In Gellner, David, Pfaff-Czarnecka, Joanna and Whelpton, John. (Eds.). Nationalism and Ethnicity in a Hindu Kingdom: The Politics of Culture in Contemporary Nepal. Amsterdam: Harwood Academic Publishers. p. $3-32$. 
Ghising, R. (2015, May 23). 'Āfailāī pardā thāhā hudo raheca'. Kantipur Dainik. 23:94. [2072 Jestha 9]. Kathmandu: Kantipur Publication Pvt. Ltd. p. 15.

Korn, W. (1998). The Traditional Architecture of the Kathmandu Valley. Kathmandu: Ratna Pustak Bhandar.

Nepal, G. (2015, May 12). "Sucanā dina baneko thiyo Dharaharā". Naya Patrika Dainik. 9:28. Retrieved from www.enayapatrika.com/2015/05/5722 on 14 December 2015. Kathmandu: Naya Publications Pvt. Ltd.

Nepal Samacharpatra. (2015, May 6). "The fall of Kasthamandap". Nepali Times. No. 757. [8-14 May 2015]. Retrieved from nepalitimes.com/article/from-nepali-press/The-fall-ofKasthamandap,2234 on 14 December 2015 Monday.

Neupane, G. P. (2016, December 24). "Mandala found at Kasthamandap Foundation". Republica. Retrieved from myrepublica.nagariknetwork.com/news/11725 on 25 December 2016.

Pant, M. R. (2013, January 14; reprinted 2015, April 28). "Nepālamā Bhūkampako Nālībelī" [An Account of Earthquake in Nepal]. Rajdhani. 12:216. Lalitpur: Rajdhani News Publications Pvt. Ltd. p. 7. (2015a, July 31). "Kāṣthamaṇụapa kati purāno? Kasale banāyo?" [How old is Kasthamandap? Who constructed it?]. Rajdhani. Lalitpur: Rajdhani News Publications Pvt. Ltd.

(2015b, September 1). "Kāṣṭhamaṇụapasãga Līlāvajrako sambandha" [Relation of Lilavajra with Kasthamandap]. Rajdhani. Lalitpur: Rajdhani News Publications Pvt. Ltd.

Pfaff-Czarnecka, J. (1997). "Vestiges and Vision: Cultural Change in the Process of Nation-Building in Nepal" In Gellner, 
David, Pfaff-Czarnecka, Joanna and Whelpton, John. (Eds.). Nationalism and Ethnicity in a Hindu Kingdom: The Politics of Culture in Contemporary Nepal. Amsterdam: Harwood Academic Publishers. p. 419 - 470.

Pokhrel, H. (2015). Ahilesamma Gaeka Vināśakārī Bhūkampako Nālībelī: Mahābhūkampa 2072 [An Account of Disastrous Earthquakes till Now: Giant Earthquake 2015]. Kathmandu: Brother Books Publications Pvt. Ltd. ISBN: 978-9937-8916-3-9.

JBR, B. S. (1991, reprint 2015). Nepālako Mahābhūkampa: 1990 Sāla [A Giant Earthquake of Nepal: 1990 BS / 1934 AD]. Kathmandu: Ratna Pustak Bhandar.

Rajopadhyaya, A. D. (2018). Dharaharā vs. Kāṣțhamaṇḍapa Coverage Post 2015 Gorkhā Earthquake: Critique on the Educational Role of Media. In Bista, J. (ed.). KCC Media Journal. 2:1. pp. 39-47.

Risal, D. (2015, September 3). Kasthamandap: Microcosm of Kathmandu's Living Culture and Storied History. Asianart.com.

Slusser, M. S. (1982). Nepal Mandala: A Cultural Study of the Kathmandu Valley. (II vols). New Jersey: Princeton University Press.

Subedi, R. (1984). "Nepalako Dharahara". Ancient Nepal. No. 80 [February-March 1984]. Kathmandu: Department of Archaeology, Nepal Government. p. 13-17.

Thapa, R. J. (1968). "Kashthamandap". Ancient Nepal. No. 3 [April 1968]. Kathmandu: Department of Archaeology, Nepal Government. p. 41-43.

The Kathmandu Post. (2015 April 26, 6:18 pm). "Historical monuments lost forever". The Nation. Retrieved from www.nationmultimedia.com/breakingnews/Historical- 
monuments-lost-forever-30258805.html on 14 December 2015 Monday. Bangkok: The Nation Multimedia.

Wright, D. (Ed.). (1990). History of Nepal: With an Introductory Sketch of the Country and People of Nepāl. New Delhi: Asian Publication Services. [First edition 1877, Cambridge; translated from Parbattiyā by Munshī Shew Shunker Singh and Pandit Shrī Gunānanda].

\section{Appendices: Illustrations}

1. Dharahara: Then and Now

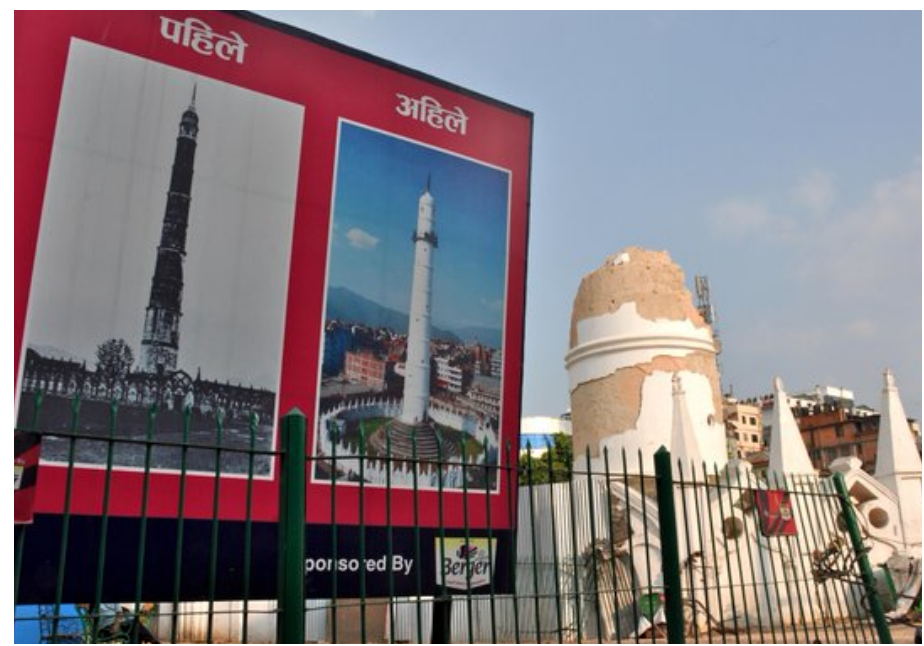

A poster comparing photographs of Dharahara before 1934 earthquake and in the new century, against the background of the post Gorkha-earthquake 2015 remains of Dharahara

Source: Tweeted by @anshuedc (1 June 2015, 11:53 am) 
2. Kasthamandap: Then and Now [Compilation]

Then $\quad$ Now

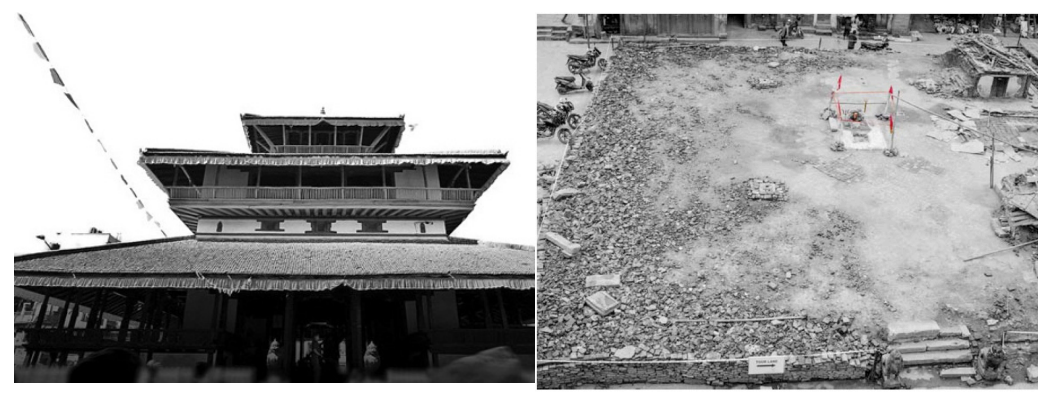

Source: Rajdhani Daily (1 Source: Risal (2015:4).

September 2015)

Photo by: Sameer Tuladhar.

3. Dharahara as symbol for enormity of earthquake devastation

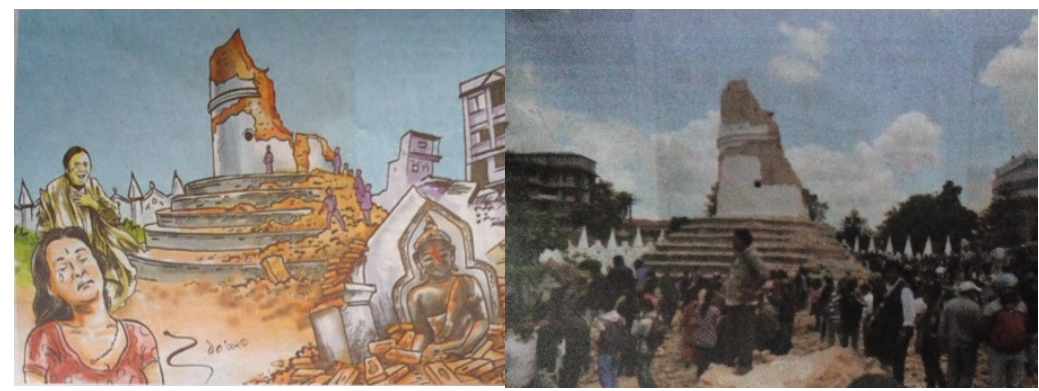

Source: Nagarik Dainik (14 Source: Naya Patrika Dainik (28 May $2015 \quad$ April 2015 |

31 Baisakh 2072, Thursday) 15 Baisakh 2072, Tuesday) 
4. Dharahara as symbol for revival
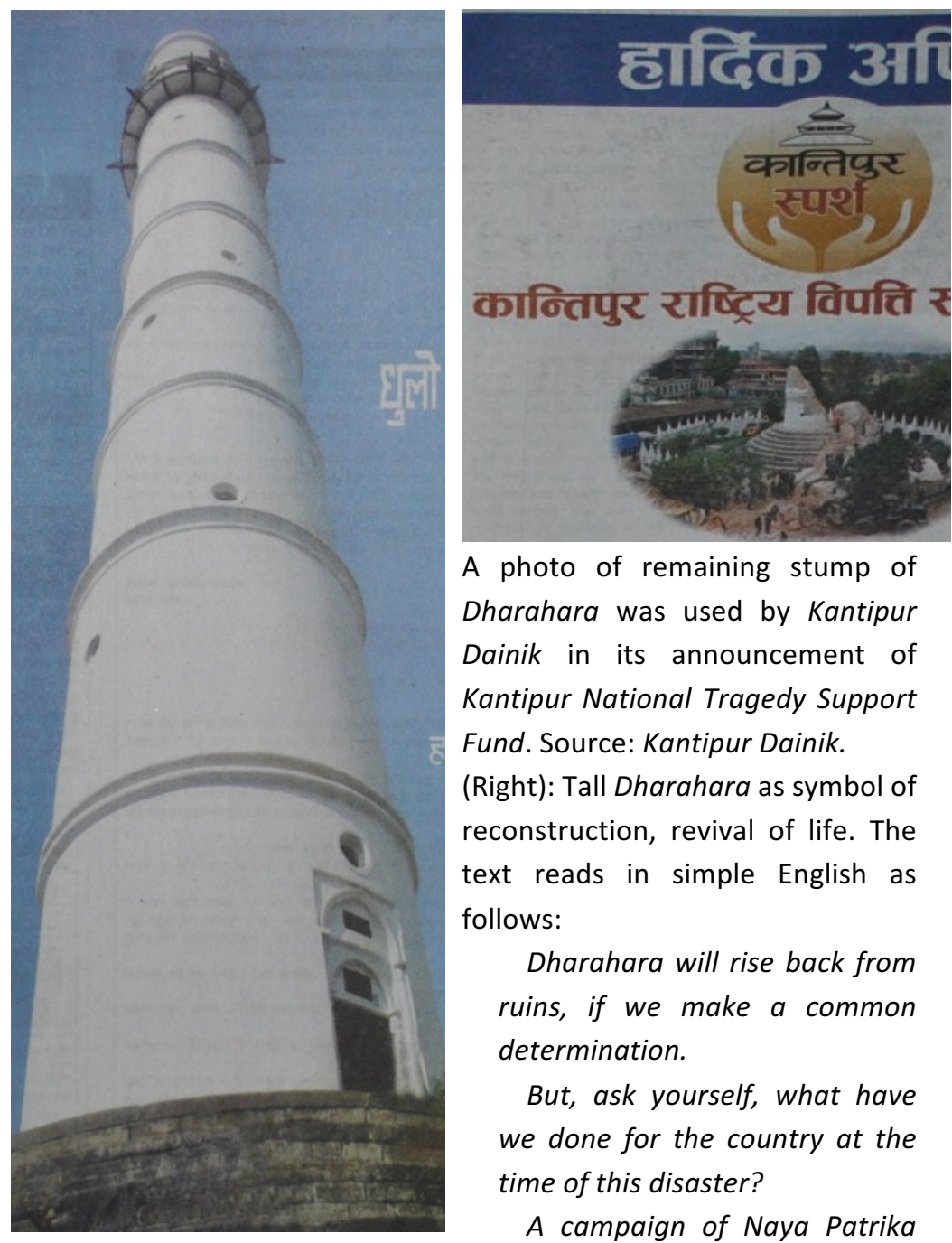

A photo of remaining stump of Dharahara was used by Kantipur Dainik in its announcement of Kantipur National Tragedy Support Fund. Source: Kantipur Dainik. (Right): Tall Dharahara as symbol of reconstruction, revival of life. The text reads in simple English as follows:

Dharahara will rise back from ruins, if we make a common determination.

But, ask yourself, what have we done for the country at the time of this disaster?

A campaign of Naya Patrika for national self-determination.

"Source: Naya Patrika 
5. Dharahara as a uniting force

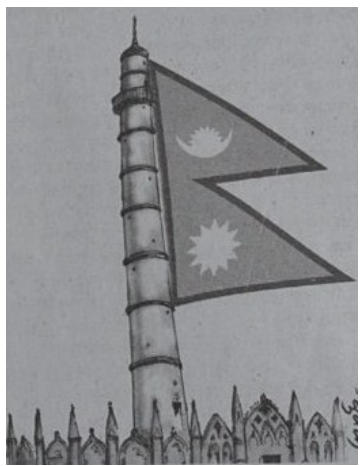

Source: Nagarik Dainik (29 Baisakh 2072 | 12 May 2015) in an article by Gopinath Mainali

\section{End note}

The author would like to extend gratitude to Prof. Rama Krishna Regmee, Dr. Mahes Raj Pant and Nutandhar Sharma for their suggestions. I also thank Department of MCJ at Kantipur City College, Apsara Karki Rana, journalists Shanti Bikram Gautam, Dipak Prasad Sapkota, my parents Er. Om Dharananda Rajopadhyaya and Sarala Rajopadhyaya for their support in preparing this article. I take the responsibility for the article. I have made use of International Alphabet for Sanskrit Transliteration (IAST) symbols for correct reading by foreign readers as well. However, in some cases, I have tried to retain popular spellings with diacritical marks. The input from this article has also been used in another publication Rajopadhyaya (2018).

The author works at the Department of Mass Communication \& Journalism, Kantipur City College, Kathmandu. Email: abhas@kcc.edu.np 